\title{
Os retábulos da nave e da sacristia da igreja da Companhia de Jesus em Belém do Pará
}

The retables of the nave and the sacristy church at Society of Jesus of Belém of Pará

Iaci Iara Cordovil de Melo*

\section{Resumo}

Este artigo trata de arte setecentista de talha, especificamente os retábulos remanescentes na nave e sacristia da antiga Igreja de São Francisco Xavier construída pela Companhia de Jesus em Belém do Pará, hoje rebatizada como Santo Alexandre e que desde 1998 integra o acervo do Museu de Arte Sacra, localizado na própria Igreja e no antigo colégio. A pesquisa apresenta análises técnicas, estilísticas e iconográficas de estatuária e carpintaria integradas na arquitetura produzidas nas oficinas do colégio, sob a orientação dos qualificados padres e irmãos da assistência portuguesa. A utilização de mestre de obras e oficiais mecânicos, formados na região a partir da mão de obra disponível (índios, negros e noviços), visavam à conversão, a aculturação e, sob certa medida, a independência artística da Metrópole, em consonância com o eficiente projeto catequético da Ordem na Europa.

\section{Palavras-chave}

Companhia de Jesus; Oficina de escultura e talha; Talha setecentista; Irmãos artífices europeus; Mão de obra indígena e negra.

\footnotetext{
* Licenciada em Educação Artística - Habilitação em Artes Plásticas pela UFPA, Especialista em História da Arte pela PUC-MG, Especialista em Cultura e Arte Barroca pela UFOP-MG, Cursou a Especialização em Arte Sacra pela FAM-Mariana/MG, Mestre em Artes pela UFMG. E trabalha na Secretaria de Cultura do Estado do Pará no Departamento de Patrimônio do Estado do Pará - SECULT/DPHAC-PA.
} 


\begin{abstract}
This work deals with carving of the XVIIIth, specifically remaining altarpieces in the nave and sacristy of the former church of São Francisco Xavier, built by the Society of Jesus in Belém do Pará. It was renamed as Santo Alexandre and since 1998 integrates the collection of the Museu de Arte Sacra, located in the church and the old school. The research presents technical, formal, stylistic and iconograpfhic analyses of the material produced in the workshops of the College, regarding statuary, carpentry, metal work, painting and gilding, under the guidance of qualified priests and brothers of the portuguese support. Utilization of construction foremen and officials trained in the region from the workers available (indians, blacks and novices), aimed at the convertion, acculturation and, on a certain extent, the independence of Metropolis artistic guidance, in line with the efficient catechetical project of the Order.
\end{abstract}

\title{
Keywords
}

Society of Jesus; Office of sculpture and carving; Eighteenth carving; European brothers craftsmen; Indian and black labor.

\section{Recibido: 10 de diciembre de 2013}

\section{Evaluado: 12 de enero de 2014}




\section{Introdução}

Erguida na cidade de Belém entre os séculos XVII e XVIII, a antiga Igreja de São Francisco Xavier (hoje Santo Alexandre) é, entre os monumentos sobreviventes, o expoente maior da aventura dos padres e irmãos da Companhia de Jesus na então Província do Grão Pará e Maranhão.

Os jesuítas, instalados na capital do Brasil desde 1549, seguiram no processo de catequização rumo ao Maranhão em 1626, onde construíram o Colégio Nossa Senhora da Luz. Na década seguinte, seu empreendedorismo os fez seguir até o Pará, sob forte tensão psicológica no ar, surtos epidêmicos trazidos pelos europeus, naufrágios e com isso, se fixando na região apenas em 1653.

A partir de então a extensa atividade inaciana na região dividiu-se entre as questões temporais e espirituais. O complexo (templo e o colégio) de Belém tornou-se o comando administrativo das outras casas localizadas nas aldeias missionárias ou em fazendas, que funcionavam como suporte econômico até a derrocada que culminou na expulsão em meados do XVIII.

A igreja teve três construções, sendo que a última recebeu rica ornamentação em cumprimento ao eficiente projeto catequético no Brasil e na Europa para áreas urbanas visando o sucesso do catolicismo, o que exigiu a feitura de uma grande quantidade de peças sacras pintadas, esculpidas ou entalhadas na madeira que abasteceram capelas e igrejas sertão adentro no Pará.

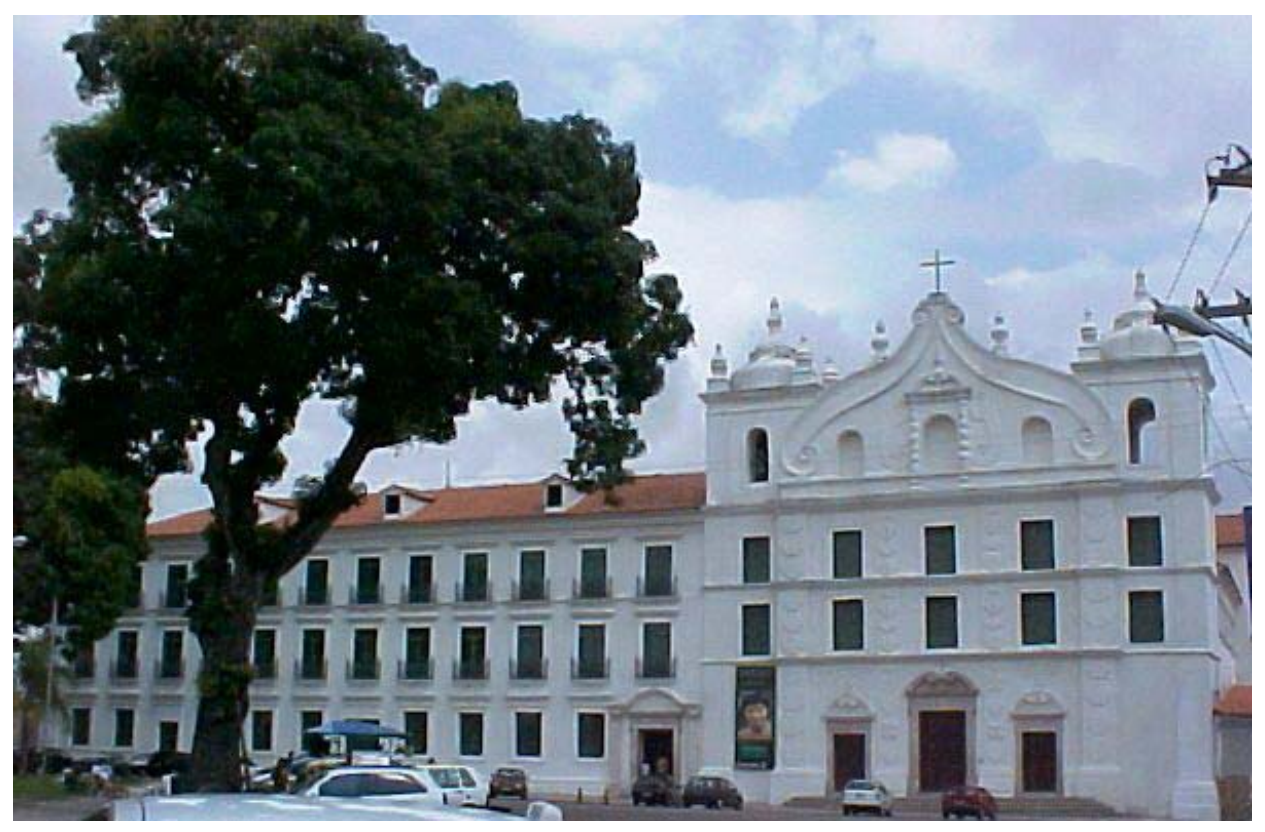

Figura 1: Fachada da Igreja de São Francisco Xavier (Hoje Santo Alexandre). Fonte: Foto de Iaci Iara Melo. 


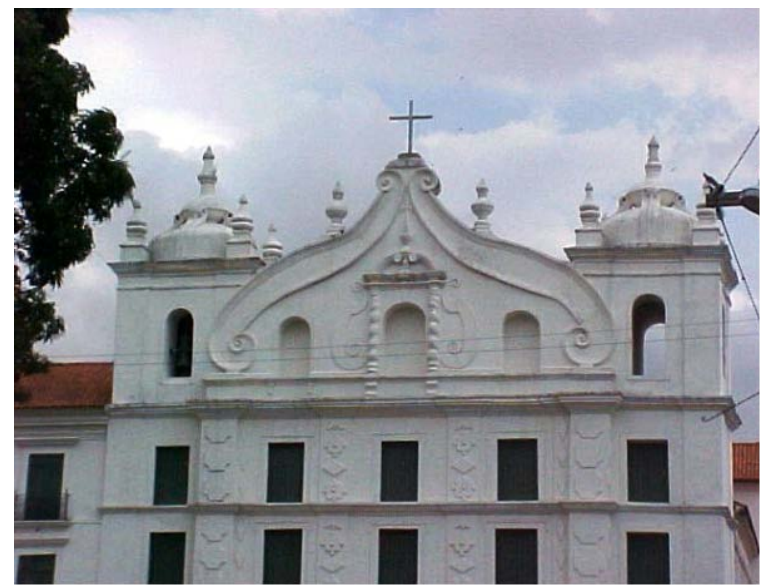

Figura 2: Detalhe do arremate superior da fachada. Fonte: Foto de Iaci Iara Melo.

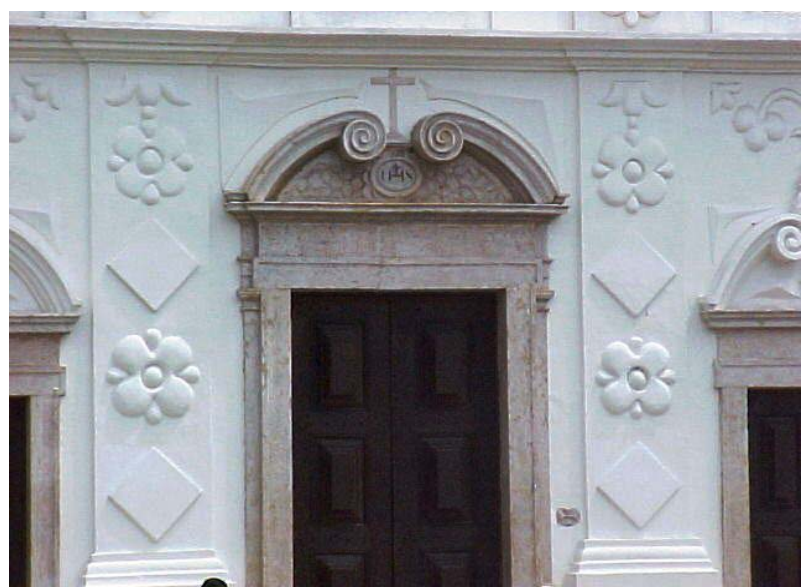

Figura 3: Detalhe da decoração sobre as pilastras na fachada. Fonte: Foto de Iaci Iara Melo.

Este artigo se restringe aos retábulos da nave (capelas laterais e transepto) e sacristia, mas vale salientar que o conjunto completo da talha setecentista compreendia originalmente os impetuosos púlpitos e a arte retabilística na capela doméstica ${ }^{1}$, sacristia, capela-mor, duas capelas no transepto, e um conjunto de seis capelas laterais na nave.

As peças vinham inicialmente de Portugal, mas logo foram organizadas oficinas que formavam oficiais mecânicos a partir da mão de obra disponível na região (índios, negros e noviços) sob as orientações de padres e irmãos capacitados da assistência portuguesa visando à conversão e aculturação e sob certa medida, independência artística da Metrópole e foram desenvolvidas a partir de adaptações materiais que asseguraram a auto-suficiência dos trabalhos.

Os primeiros nomes de artífices que aparecem como responsáveis pela suntuária jesuítica no colégio do Pará são os dos irmãos pintores João de Almeida (francês), Baltasar de Campos (flamengo) e José de Moura (?), ainda no final do XVII, e que instituem na região um marco inicial. De outra parte, a primeira referência sobre a existência das oficinas de talha nas dependências do prédio data de 1718, conforme indica Lamego:

No pedaço do corredor novo, pelas cordas da capela-mor em que ficam, duas janelas, rasgadas para baixo com grades, uma para cima com gelozias, dois cubículos, um para botica e serve entretanto ao Irmão escultor e rapazes que aprendem e por cima com gelozias, da mesma sorte, outros dois cubículos, um para o P. Superior, servindo um para a cama e livraria e o oratório e outro para sala de consultas com uma janela rasgada para o nascente ${ }^{2}$.

\footnotetext{
${ }^{1}$ Localizada acima da sacristia, em igual tamanho, utilizada pelos padres ou para atendimento da comunidade. Após 1998, abrigou a Sala da Memória e atualmente funciona o auditório do Museu de Arte Sacra.

${ }^{2}$ Lamego, 1925: 357.
} 
Nesta época já se encontrava em Belém outro exímio artífice, talvez o de maior destaque, o irmão João Xavier Traer (Treyer) de Brixen, Áustria, pintor e escultor que se estabeleceu no Pará entre 1703 e 37, ano de seu óbito. A ele tem sido atribuída a divulgação do estilo joanino na Igreja de São Francisco Xavier e a organização das oficinas. Atuou em conjunto com os irmãos Luís Corrêa (mestre de pintura e dourador) e André Gonçalves (carpinteiro, e possivelmente entalhador e escultor) ${ }^{3}$ ambos lisbonenses. O quadro do pessoal da casa do Pará incluía, em 1718, conforme nos diz Leite:

Carpinteiros: Inácio e Feliz, pretos, escravos da Fazenda de Jaguarari, Antônio Guaiapi, Raimundo Tupinambá e Mandu Gregório, da Fazenda de Maiacu; Américo e João, índios, deixados ao Colégio; Mandu, cafuz, escravo do Engenho de Ibirajuba. Escultores: Manuel, Ângelo e Faustino, índios de Gibirié, escravos ${ }^{4}$.

O que implica dizer que embora a primeira menção acerca da localização das oficinas no prédio se dê em 1718 por Lamego (1925), a lista da equipe de trabalho (índios e negros) apresentada por Leite (1943), refere-se ao grupo como pertencentes a um determinado ofício, e não apenas na condição de simples aprendizes ${ }^{5}$. Este número cresce à medida que se incluem torneiros, pedreiros, ferreiros, alfaiates e tecelões, e parece plausível dizer que a escola de talha à época encontrava-se em franco desenvolvimento.

Um outro nome de destaque constava entre os deportados de 1759: "Padre João Teixeira, decrepitus. (Muito concorreu para o enbellezamento da Igreja do Collegio do Pará, dourou todos os retábulos)” ${ }^{\text {. }}$. Embora quando chegado o documento de expulsão, este era falecido desde 1757.

Interessante pensar que muitas vezes os padres que estavam à frente ou na supervisão das obras para êxito dessa decoração, como é o caso de Bettendorf no XVII e João Teixeira no XVIII que possuíam formação superior em conceituadas faculdades de artes na Europa, diferente dos engenhosos irmãos em Portugal, que eram homens brancos de classes sociais menos favorecidas, que aprendiam a profissão em uma oficina durante anos até a obtenção da autorização para o trabalho.

Vale dizer, que estes magistrais artífices eram poucos na empreitada amazônica; desdobravam-se com as tarefas domésticas, com o exercício de um ofício principal e um ou dois secundários no programa iconográfico da Companhia de Jesus na região.

\footnotetext{
${ }^{3}$ Bogéa, Ribeiro e Brito dizem que o irmão Gonçalves “[...] morreu em 1728, ainda jovem, no Colégio do Maranhão, recebendo os sufrágios devidos aos religiosos da Companhia e mais ainda os de 'insigne benfeitor' dos dois colégios, o que indica que prestou grandes serviços aos colégios do Pará e do Maranhão”. (Bogéa; Ribeiro; Brito, 2002: 55.

${ }^{4}$ Leite, 1943: 25.

${ }^{5}$ Segundo Toledo (1983) em Portugal oficial é aquele que exerce o ofício; oficial examinado, o que submetido a um teste prático, conseguiu licença para o exercício da atividade; mestre de tenda é o artífice, que além de examinado possui sua própria oficina; e o obreiro ou aprendiz como sendo o que trabalha sobre as ordens do mestre, recebendo pagas na tenda do outro. Entretanto, no Brasil essa formação e os regimentos não seguiam critérios tão rígidos.

${ }^{6}$ Lamego, 1925: 306.
} 
Um exemplo desse acúmulo de ações talvez seja a função do ensamblador no XVIII, pois não encontramos referências (até o momento) de tal oficial. E é possível que esta atividade fosse desenvolvida por escultores ou entalhadores da casa.

A expulsão dos jesuítas ocorre em 1759/1760 e trouxe momentos distintos à igreja, que primeiro ficou ao abandono e depois foi cedida por seus novos proprietários: a Ordem do Santo Cristo e logo em seguida à Irmandade da Misericórdia, passando por reformas e modificações diversas que resultaram na diminuição do camarim na capela-mor, na possível perda de retábulos em madeira, na feitura de novos retábulos em massa e na reconstituição da peça da capela do transepto.

Os tempos são outros e a travessia durante o século XX trouxe ventos não muito propícios nos quase cinqüenta anos em que o templo permaneceu fechado, até a sua recuperação, no final do período quando foi transformado pelo Governo do Estado de casa de oração para Museu de Arte Sacra. Nesse ínterim, até sua reabertura, a talha sofreu com cupins, goteiras, umidade e mofo, perdendo o seu douramento, e que por uma opção museográfica foi mantida crua.

\section{Os retábulos nas capelas da nave}

Os objetos de análise reunidos neste artigo: capelas laterais da nave, transepto e a sacristia, possuem talha com aspectos característicos do último quartel do XVII e das primeiras décadas do XVIII, período correspondente a organização das oficinas no colégio e data de sua provável execução.

A nave, através das capelas laterais e do transepto convidam o crente a percorrer o caminho dos sinais da presença de Deus, diante do esplendor da arte da talha (uma conjugação de mobiliário, arquitetura e ourivesaria) e da imaginária, atuando como expressão estética e didática ${ }^{7}$.

A decoração em talha ${ }^{8}$ nas capelas constitui-se essencialmente de retábulos (retro + tabla $=$ atrás + altar) para abrigar e expor as representações das imagens dos santos dedicados à oração.

A sacristia cuidadosamente trabalhada, como costumeiramente ocorria nas igrejas jesuíticas, tem mobiliário, retábulo e molduras que outrora se destinavam a pintura parietal. Este espaço, reservado aos sacerdotes para preparação do culto é do mesmo comprimento que a capela-mor, e o acesso pode ser realizado pela própria capela, pelo transepto, pelo pátio e pela área do colégio e da antiga residência dos irmãos, atualmente ocupada pela administração do museu.

\footnotetext{
${ }^{7}$ Hoje os camarins nos retábulos das capelas laterais encontram-se sem as imaginárias por uma opção museográfica.

${ }^{8}$ Característica da atividade de oficiais portugueses, a madeira é uma expressão econômica mais pobre do que o mármore, porém desenvolvida por esses profissionais com maestria na suntuária religiosa.
} 


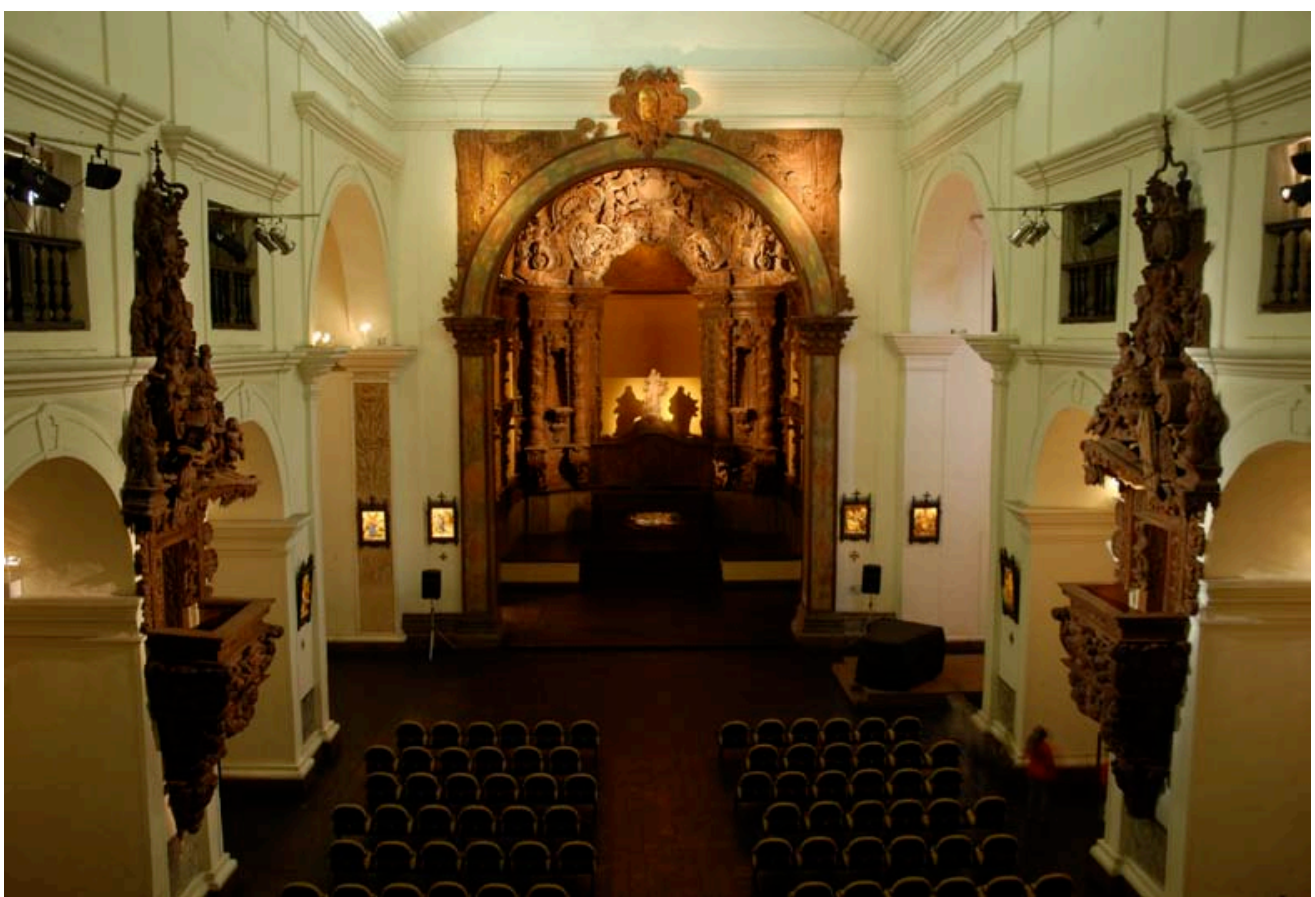

Figura 4: Decoração interna da Igreja de São Francisco Xavier - Vista geral da nave e capela-mor. Fonte: Foto de Marcelo Soares.

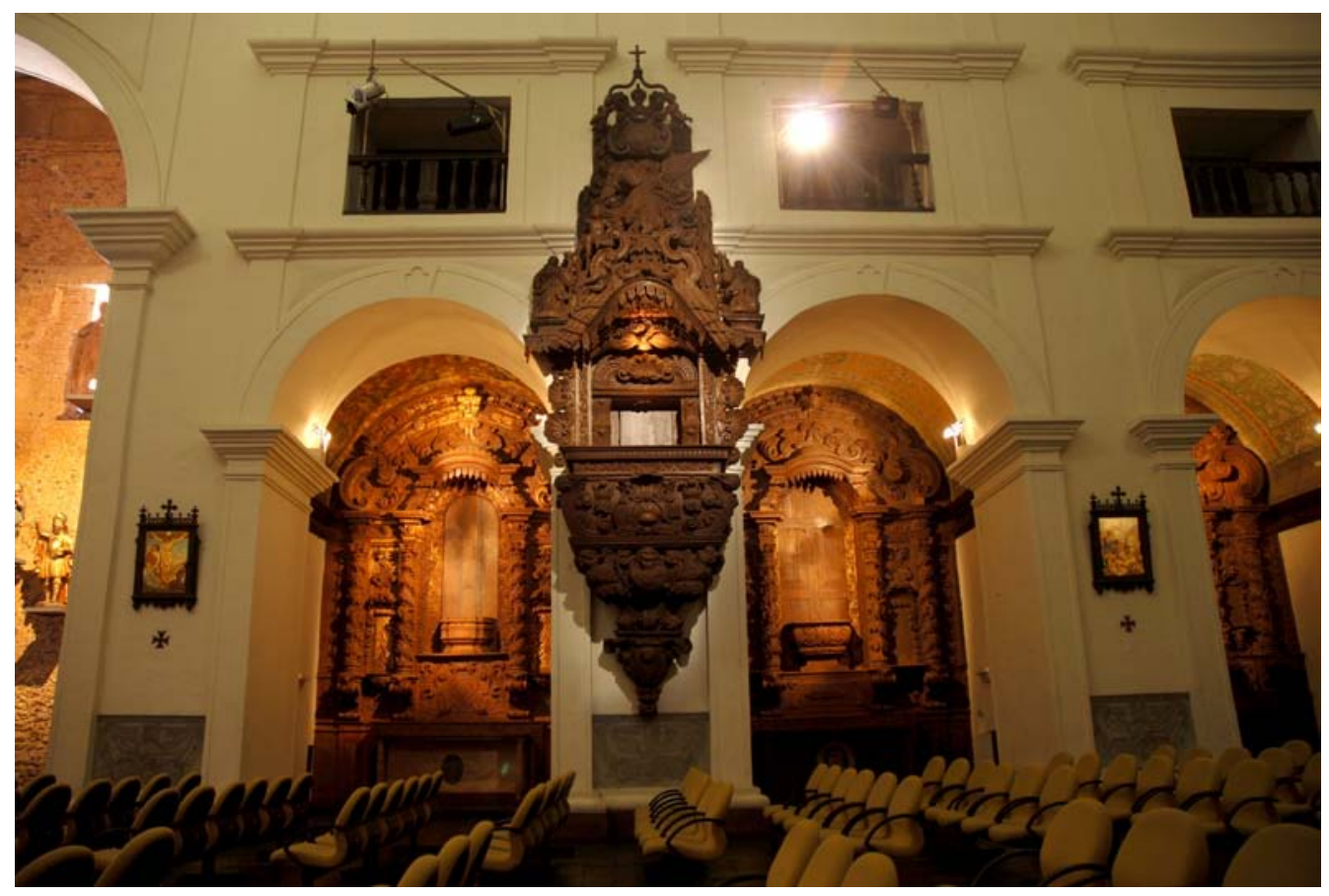

Figura 5: Vista panorâmica das capelas laterais. Fonte: Foto de Marcelo Soares. 


\section{Análise material e técnica}

A madeira utilizada para a aplicação da talha foi o cedro vermelho ${ }^{9}$, adquirido no centro de distribuição jesuítico localizado na Fazenda Itapecuru, nas proximidades do rio de mesmo nome, em terras do Maranhão.

A razão da escolha pela cedrela, deve-se a esta ser de fácil manuseio, dada a sua maciez para entalhe e sabor amargo para o seu principal inimigo: os cupins. Ressalte-se, porém que era costume ter na armação uma madeira mais rígida; não se sabe até o momento que madeira era utilizada.

Após a seleção da matéria-prima, os troncos podiam receber apenas um primeiro desbaste ou ser já desdobradas em tábuas. O material seguia de navio para Belém levados pelos religiosos até o Colégio em Belém ${ }^{10}$.

O trabalho de entalhe era realizado nas oficinas do Colégio, utilizando-se ferramentas como facas, machados, formões, cunhais e brunidores (estes geralmente em ágata), confeccionados por serralheiros, ferreiros e fundidores. Prontas, as peças eram encaixadas por carpinteiros nas capelas, onde a superfície da madeira era preparada para a policromia e para o moroso douramento ${ }^{11}$.

As etapas comumente realizadas consistiam em polimento da obra com lixa, aplicação de cola (de cartilagem de coelho e no Grão-Pará ventila-se a possibilidade do grude da gurijuba) para correção de imperfeições, depois uso de gesso-cola e gesso-mate com certa espessura, onde se repetiam as aplicações que iam do grão mais grosso até alcançar uma granulação mais fina para que se fosse dado novo polimento, de modo a obter uma superfície regular. Por fim, como mordente era empregado o bolo-armênio: fina argila diluída em água, com gotas de cola, geralmente de cor marrom.

Alcançado o nível de umidade ideal, a madeira aparelhada era untada com goma arábica, para então receber as pequenas folhas de ouro, aplicadas uma a uma. No caso da Igreja de São Francisco Xavier, segundo Lamego (1925), o metal utilizado foi o carmesim $^{12}$. Depois de secas, utilizava-se o brunidor de ágata integrando a estrutura da folha com o bolo armênio, fixando dando brilho às peças.

\footnotetext{
${ }^{9}$ Em Portugal, conforme Smith (1962), a madeira preferida para a confecção da talha dos retábulos era o bordo, oriundo de outros países, e na sua ausência utilizava-se o castanho. Para a armação, adotavam o carvalho vindo do Norte da Europa e para as peças pequenas o buxo ou o cipreste. Na lista constam também laranjeira, loureiro, nogueira, faia, frexeiro, macieira, cerejeira, ameixeira, ulmo, ginjeira, entre outros.

10 "Os colégios do Pará e Maranhão funcionavam como grandes fornecedores de objetos artísticos para a decoração de igrejas e capelas nas missões. Suas oficinas dispunham de profissionais que iam desde um simples peão até os qualificados irmãos vindos de Portugal, França e Áustria que se dividiam muitas vezes entre os dois colégios. Entretanto, não se desprezam a existência de pequenas oficinas em fazendas pelo sertão, organizadas por ex-aprendizes, noviços da Companhia e/ou pelos missionários mais habilidosos.” (Bogéa; Ribeiro; Brito, 2002).

${ }^{11}$ Largamente adotado na metrópole, desde o primeiro quartel do século XVI pelas ordens religiosas, sob forte influência flamenga. Alcançou grande destaque no século XVII, sendo utilizado para dar unidade na decoração interior dos templos católicos.

${ }^{12}$ As folhas de ouro eram compradas em Portugal, produzidas pelo mestre batefolha (figura inexistente no Brasil, em virtude de proibição da fundição na colônia) sob forte controle do Rei, como aponta Ferreira-Alves: “O padrão de qualidade obedecia a critérios de grande exigência, oscilando entre vinte e vinte e quatro
} 
O douramento trabalhado, para reforçar a ideia de morada de Deus, deveria também "[...] ]antes de tudo ser entendido como um dos processos mais convincentes para a atracção sensitiva do crente[...]" 13 , assumindo um importante papel como instrumento de convencimento e comoção do fiel acerca da existência do Pai.

A ostensiva talha dourada abre espaço para policromia nos detalhes, nas esculturas antropomorfas e nos espaços lisos dos pequenos ornatos, como novamente Ferreira-Alves chama a atenção:

Se o dourado predomina nos séculos XVII e XVIII, não significa que uma policromia rica e intensa não exista; pelo contrário, é expressamente recomendado aos artistas que utilizem cores alegres, 'finas e boas', que contribuam para criar um espaço rico e diversificado onde o ouro é realçado pelos matizes polícromos. Os retábulos que eram dourados de acordo com as regras que referimos, apresentavam algumas áreas, como os vãos e os baixos, que eram pintadas, sendo o branco, o azul e o vermelho as cores mais utilizadas ${ }^{14}$.

A autora refere-se aos retábulos produzidos em Braga e no Porto. Entretanto, na igreja jesuítica de Belém essa opção cromática pode ser observada ainda hoje na primeira capela esquerda da nave (Fig. 7).

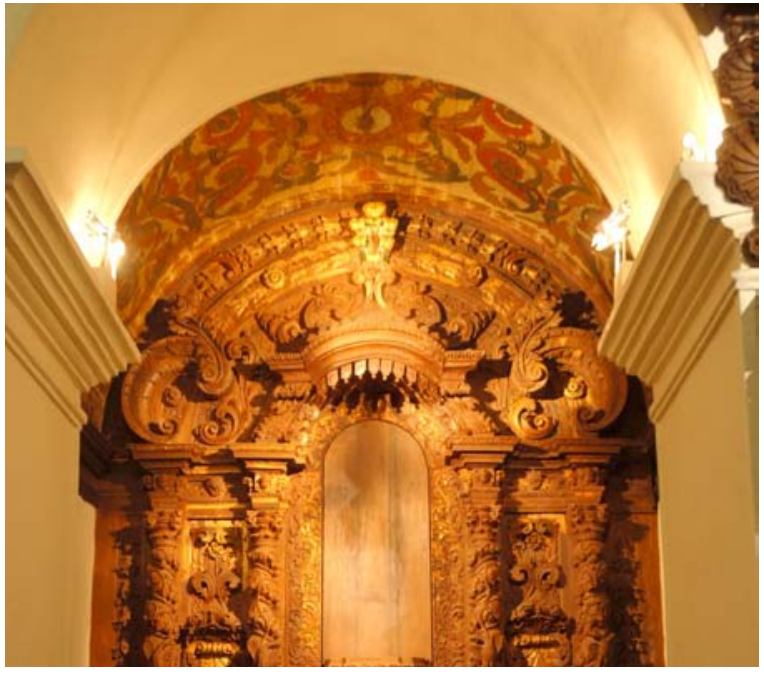

Figura 6: Retábulo com resquício de policromia vermelha, azul e branca no retábulo da capela lateral de devoção a Santo Alexandre. Fonte: Foto de Marcelo Soares.

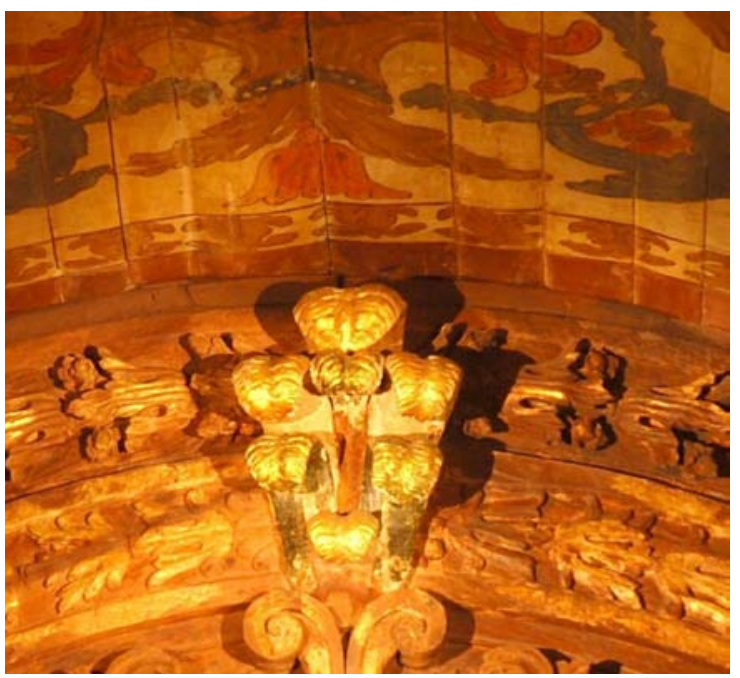

Figura 7: Detalhe ao fundo do penacho com resquício de policromia vermelha, azul e branca no retábulo da capela lateral de devoção a Santo Alexandre. Fonte: Foto de Marcelo Soares.

quilates. A sua venda era feita por milheiros, sendo cada milheiro constituído por dez livros e compondo-se cada livro por cem pães de ouro.” (Ferreira-Alves, 1989: 88). E dependendo dos metais associados a ele, resultavam em colorações diferentes, indo dos tons amarelos (misturados à liga de cobre ou prata) até aos avermelhados (com cobre, prata e zinco). Salienta-se que em geral as aplicações das folhas de ouro variavam de acordo com o efeito a ser esperado: se ouro polido ou fosco. Em se tratando de fosco, não se fazia necessária a aplicação do bolo-armênio.

${ }^{13}$ Ferreira-Alves, 1989: 183.

${ }^{14}$ Ibíd: 91. 
Embora a talha encontre-se hoje na madeira nua, há resquícios de douramento e pequena área de policromia na superfície lisa ao fundo do penacho encontrado no centro do coroamento, conforme a tendência indicada por Ferreira-Alves (1989), o que nos leva a crer na existência do mesmo tratamento visual em outras partes e nas demais capelas existentes no espaço.

Um recurso técnico de que se lançava mão para a composição da ambiência barroca era a iluminação à vela, que proporcionava um efeito interessante sobre o ouro e a policromia da talha, que brilhava sob num aparato teatral, dramatizando as expressões das imagens, com efeitos de luz e sombra valorizavam ainda mais o cenário litúrgico colocando a Eucarística como a luz do mundo.

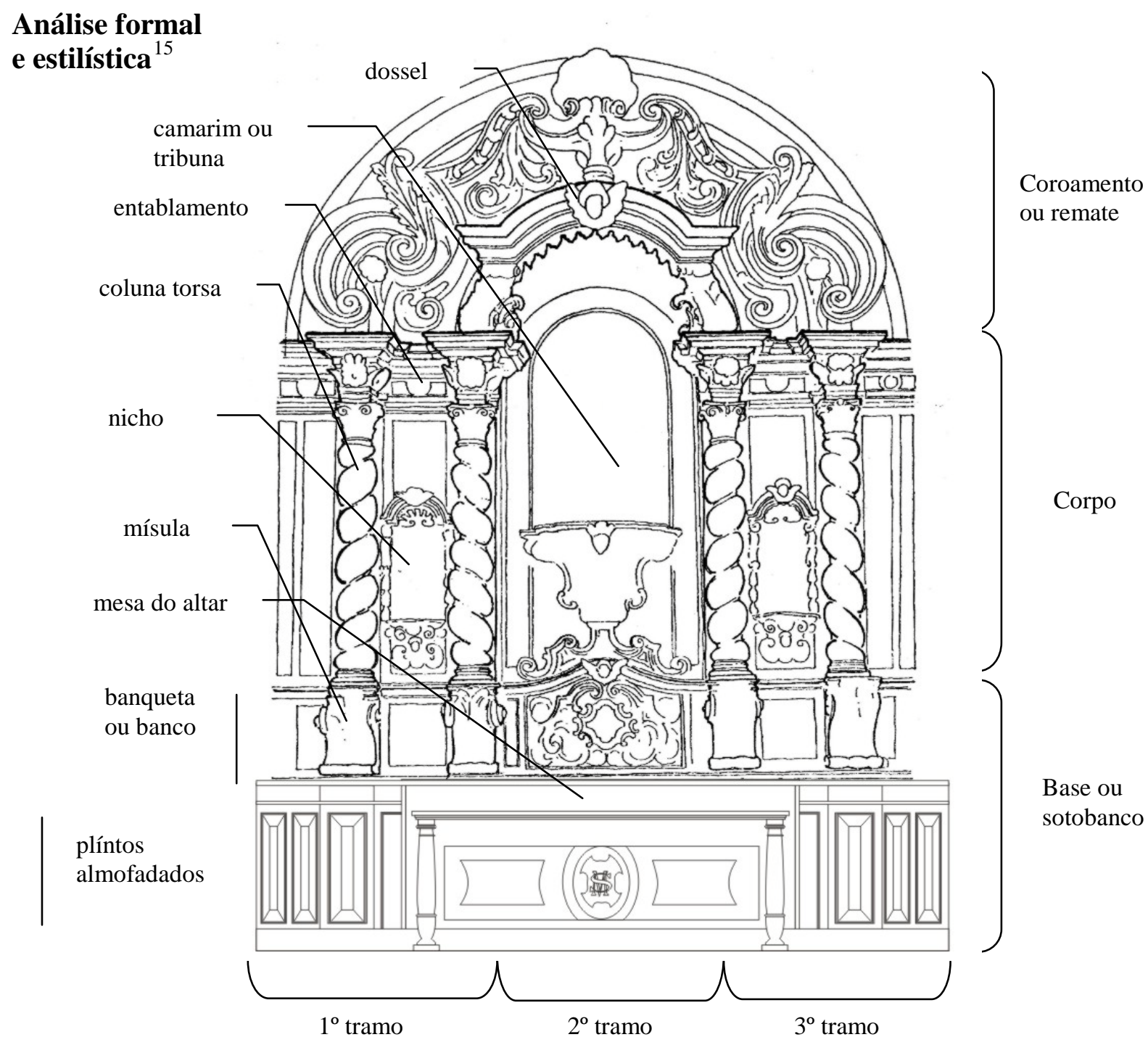

Figura 8: Desenho esquemático com a indicação dos elementos arquitetônicos dos retábulos das capelas laterais. Desenho: Antônio Sales.

\footnotetext{
${ }^{15}$ Esta análise foi baseada principalmente na observação direta do estado em que a obra se encontra atualmente.
}

43 Iaci Iara Cordovil de Melo. Os retábulos da nave e da sacristia da igreja da Companhia... 34-58 
As profundas capelas laterais da nave possuem um trabalho de talha estrutural com rasa volumetria e mesmo risco, apresentando pequenas variações nos registros horizontais dos nichos e camarim e nos motivos decorativos do coroamento da primeira e segunda capela, em relação à terceira.

A base dos retábulos (Fig. 9, 10 e 11) tem mesa do altar com tampo liso, recortado ao centro por um quadrado para colocação da pedra Dara ${ }^{16}$ e moldura ornada apenas na primeira e segunda capela.

A mesa não forma caixa com frontal de altar como de costume, ao invés disso apóia-se sobre duas colunas, tendo ao fundo policromia marmoreada com as iniciais do santos homenageados na disposição dada pelo arcebispado: SA (Santo Alexandre), SJ (São José) e SM (São Miguel) respectivamente ${ }^{17}$. À mesma altura nas laterais estão plintos almofadados divididos por tramos verticais ${ }^{18}$.

A banqueta apresenta igual modelo para mísula em todos os trabalhos, servindo de base para as colunas, encoberta por folhas de acanto e conchas, projetadas à frente em plano paralelo à predela, que tem nos intercolúnios, lambris com cartelas de motivos fitomórficos, volutas em baixo relevo, distintas umas das outras, e nichos com base de secção circular no retábulo 1 e retangular no 2.

Ao centro há variações nos lambris das três capelas, tanto em relação à altura, quanto em relação à decoração, que possui no retábulo 1 e 2 baixos relevos e no retábulo 3 elementos com relevos de baixos a médios que ultrapassam os limites entre a base e a banqueta.

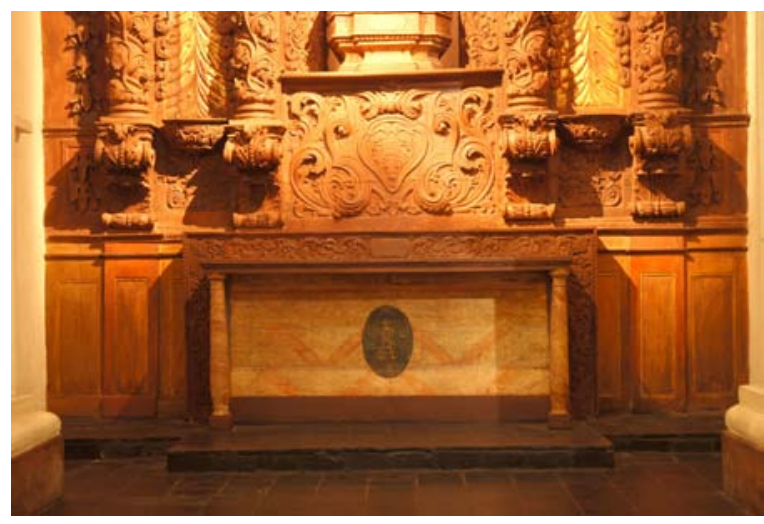

Figura 9: Mesa do altar e banqueta do retábulo com as iniciais AS. Fonte: Foto de Marcelo Soares.

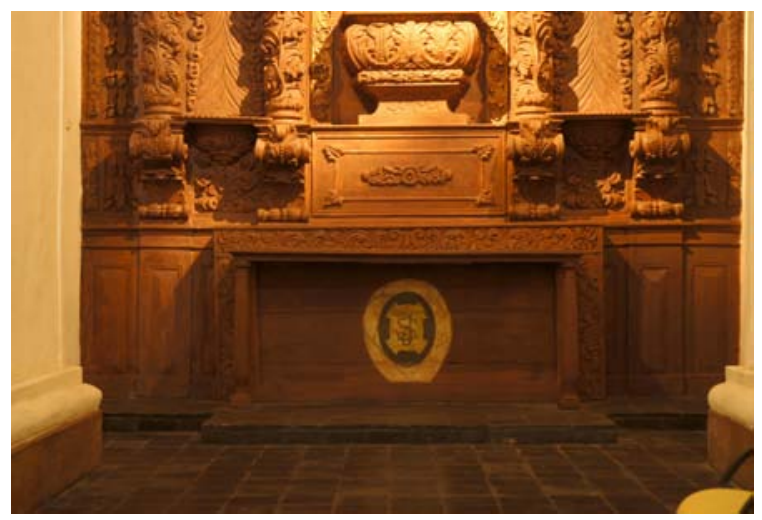

Figura 10: Mesa do altar e banqueta do retábulo com as iniciais SJ. Fonte: Foto de Marcelo Soares.

\footnotetext{
16 "Pedra retangular, pequena e pouco espessa, colocada sobre a MESA do ALTAR, tendo, no centro, pequena cavidade contendo relíquias dos mártires e dos SANTOS. Deve vir envolvida em linho grosso, e ser consagrada pelo bispo. É peça essencial do ALTAR e sobre ela repousam o CÁLICE e a HÓSTIA, na celebração da missa. Sem ela, esta se tornaria ilícita.” (Damasceno, 1987: 38).

${ }^{17}$ A partir de 1998, as imagens de Santo Alexandre e São Miguel que originalmente estariam nos nichos das capelas à esquerda da nave encontram-se por uma opção museográfica dispostas na parede do transepto à esquerda, próximos a de São Bartolomeu que se localizava na capela à direita.

${ }^{18}$ Os retábulos à direita, são peças posteriores em argamassa, entretanto, conservam a mesa do altar em madeira no mesmo modelo das capelas à esquerda.
}

44 Iaci Iara Cordovil de Melo. Os retábulos da nave e da sacristia da igreja da Companhia... 34-58 


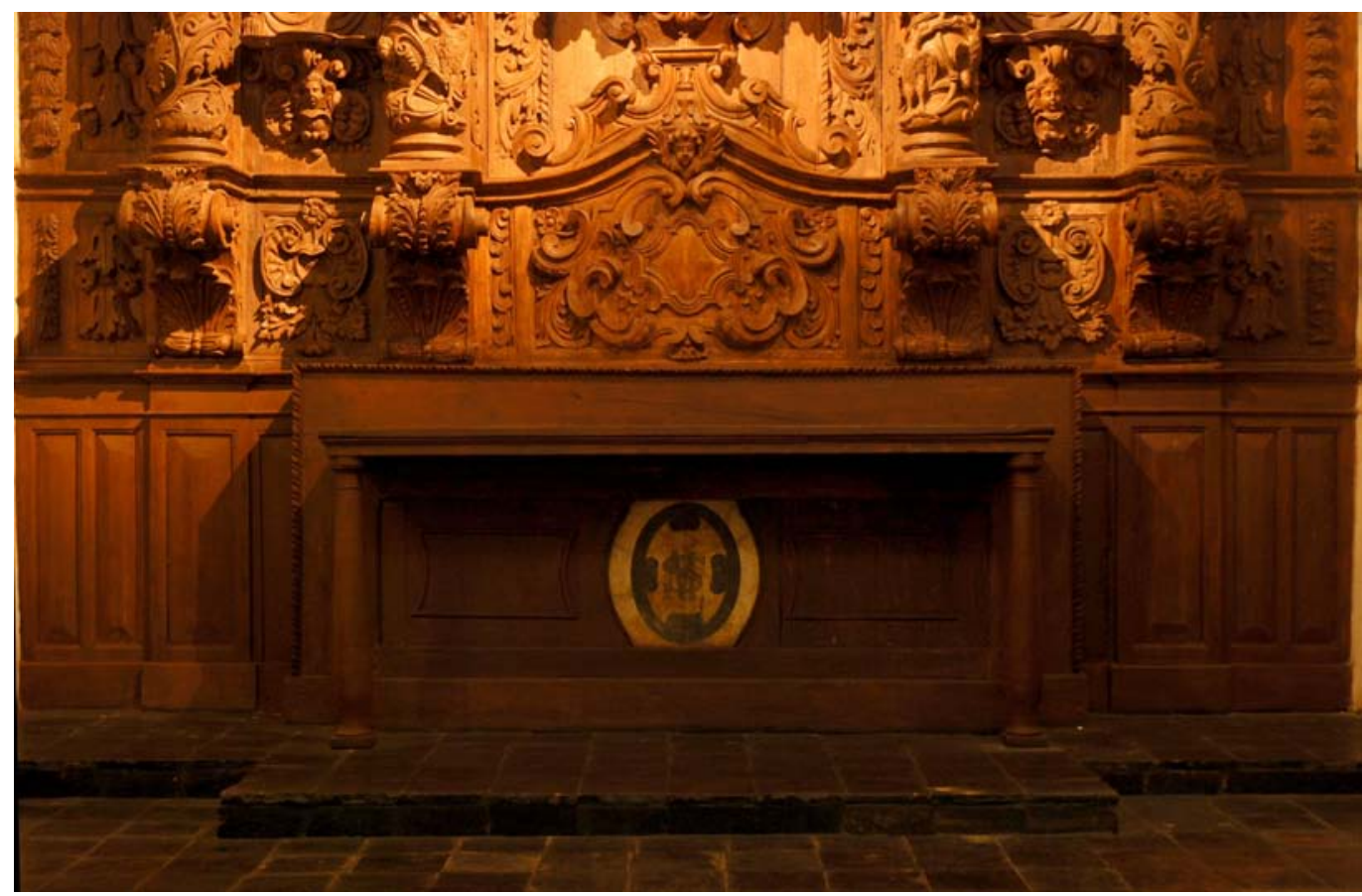

Figura 11: Mesa do altar e banqueta do retábulo com as iniciais SM. Fonte: Foto de Marcelo Soares.

O corpo do retábulo (Fig. 12, 13 e 14) corresponde à área onde a estrutura empresta lugar à expressividade escultórica nas dinâmicas linhas ondulantes dos dois pares de colunas torsas, ornadas por enrolamentos de parreiras e pássaros de igual representação e tamanho que se encontram a meio corpo das colunas com frutos da videira na boca, variando apenas na gestualidade da cabeça.

O retábulo 3 apresenta, um número de pássaros maior, que repousam nas duas colunas próximas ao camarim, dispostos em par na área inferior e superior, unidos através do bico. $\mathrm{O}$ arremate de todas as colunas nas três capelas possui capitel compósito.

O trabalho de talha inclui um nicho entre cada par de colunas, com coroamento e base que diferem um do outro em ornato e tamanho, sendo os do terceiro retábulo menores, em função da tímida redução dos espaços intercolúnios, dando-nos, a impressão visual de um suave estreitamento desta capela em relação às demais.

Ao fundo, observa-se em todos os retábulos um cortinado fingido emoldurado nas laterais por volutas com acantos e conchas no coroamento dos nichos. Os lambris acima apresentam cartelas com elementos fitomorfos, bem como curvas e contra curvas.

Ao centro da cada peça há um camarim de grande dimensão para a colocação de esculturas sacras, sobre um trono que varia conforme a capela. Todos dispõem de madeiramento liso ao fundo, havendo uma borda com volutas seguidas de folhagens nas laterais até o forro deste espaço, à exceção do retábulo 2, onde não há elemento decorativo. 
O retábulo 1 é, o único que conserva a renda da tribuna, vê-se flores, losangos e folhagens, sendo a renda finalizada no coroamento por uma voluta de cada lado. Tal finalização repete-se no retábulo 3.

Na primeira obra de talha o trono tem formato de cálice, decorado por flores e folhagens em toda peça; a segunda, mais simples, é entalhada em forma de caixa retangular com dois registros, onde apenas o segundo é decorado, com folhagens; na terceira, o trono é fixo ao fundo do camarim, tendo no centro um grutesco (brutesco $)^{19}$ com penacho sobre a cabeça, circundado por formas espiraladas em alto, médio e baixos relevos, o que diminui o espaço destinado para a imaginária.

A estrutura do entablamento de coerência clássica segue a ordem do capitel das colunas, tendo projeções frontais sobre as mesmas, ângulos retos bem definidos e friso nos retábulos 1 e 2, decorados com alternâncias de flores e pequenas cabeças angelicais ao longo do retábulo, ao passo que no 3 há palmas.

Alguns elementos decorativos também são observados na talha aplicada como volutas e festões de flores nas extremidades laterais nos três retábulos, iniciado na altura da banqueta seguindo até o coroamento.

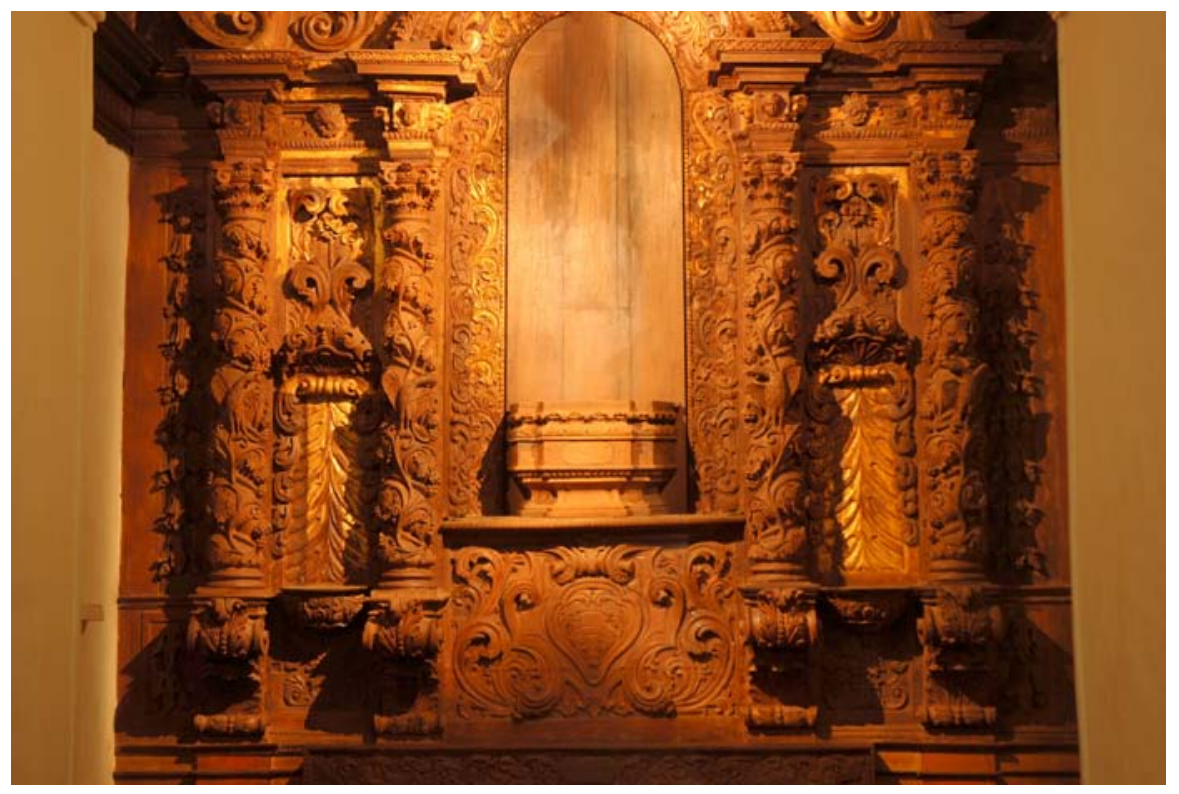

Figura 12: Corpo do retábulo com as iniciais SA. Fonte: Foto de Marcelo Soares

\footnotetext{
19،"Pintura ou escultura em que se representam grutas ou em que há ornatos de folhas, caracóis, penhascos, penedos, árvores e etc. Por extensão, ornatos que reproduzem objetos da natureza, sejam fitomorfos, antropomorfos, astromorfos, ou inspirados em animais fantásticos”. (Ávila, 1996).
} 


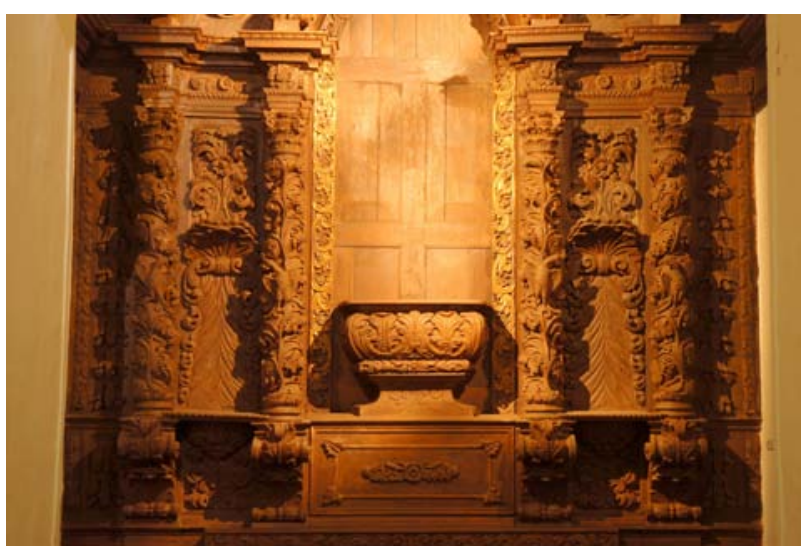

Figura 13: Corpo do retábulo com as iniciais SJ Fonte: Foto de Marcelo Soares.

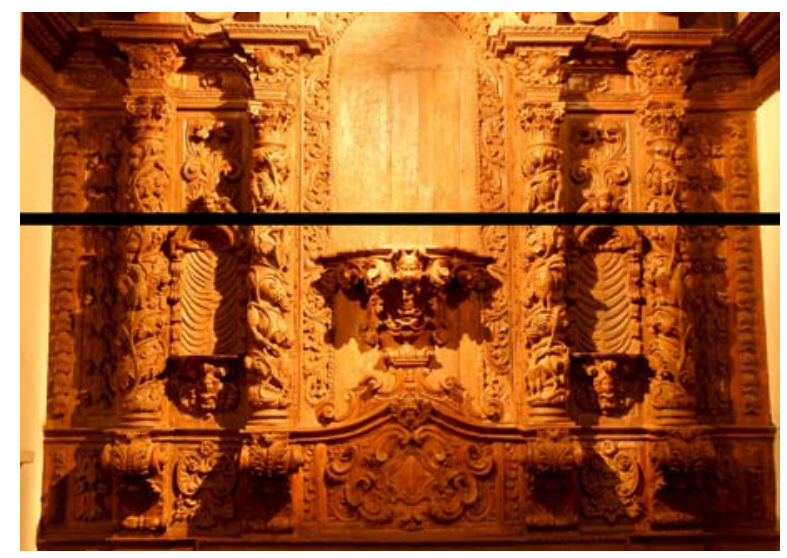

Figura 14: Corpo do retábulo com as iniciais SM Fonte: Foto de Marcelo Soares.

O remate (Fig. 15, 16 e 17) perfeitamente integrado ao corpo apresenta estrutura em arco pleno, com uma grande concha nas extremidades, apoiada sobre a projeção verticalizada do entablamento na secção das colunas, seguidas de volumosas folhas de acanto.

O tramo central está organizado a partir de um dossel lambrequinado e pingentes sobre a abertura do camarim, sendo os ornatos do retábulo 1 e 2 praticamente iguais, com variação apenas na peça central do remate, vendo-se no 1 penacho e no 2 coroa com elementos extraídos da joalheria.

O retábulo 3 tem um querubim como fecho de verga no dossel, seguido por penachos e arremate do conjunto no tramo central com uma concha, ligada pelas laterais até próximo ao entablamento por formas sinuosas. Quando comparado este coroamento com os demais, tem-se a impressão de que sua elaboração se deu posteriormente, mas ainda à época dos jesuítas ${ }^{20}$.

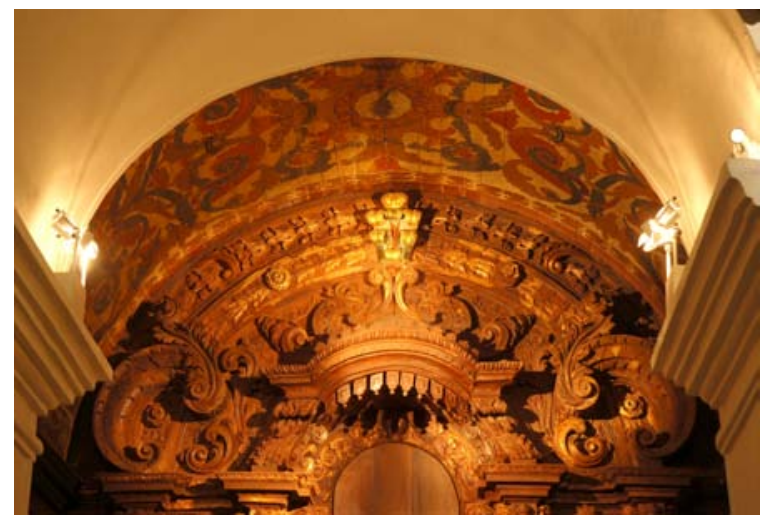

Figura 15: Coroamento do retábulo com as iniciais SA. Fonte: Foto de Marcelo Soares

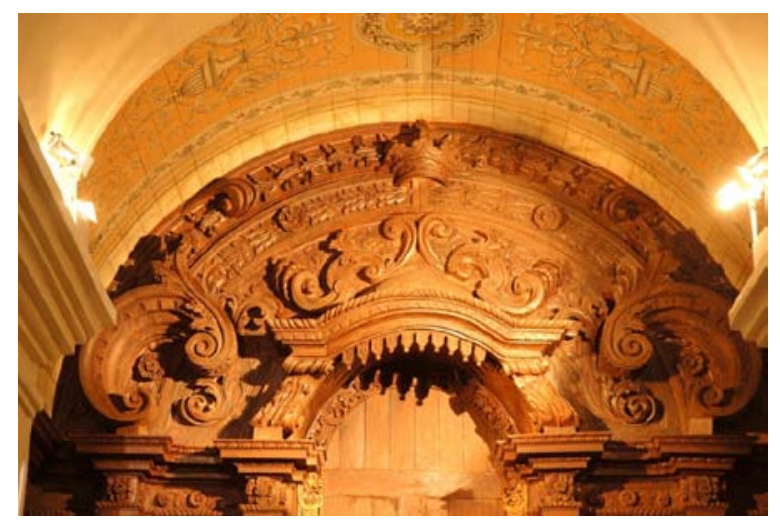

Figura 16: Coroamento do retábulo com as iniciais SJ. Fonte: Foto de Marcelo Soares

\footnotetext{
${ }^{20}$ Tal modificação talvez se justifique, porque esta capela abrigou além do Santo Cristo, ao pé do altar, segundo Lamego (1925) uma imagem de roca de Nossa Senhora da Boa Morte encomendada pelo Padre João Teixeira devoto da santa, e onde este posteriormente foi sepultado à seu pedido.
}

47 Iaci Iara Cordovil de Melo. Os retábulos da nave e da sacristia da igreja da Companhia... 34-58 
Segundo Lamego (1925) havia lambris nas laterais das capelas, que formavam uma moldura para abrigar pinturas constantes no programa iconográfico da ordem da Companhia e do conjunto devocional nas capelas, mas que inexistem hoje.

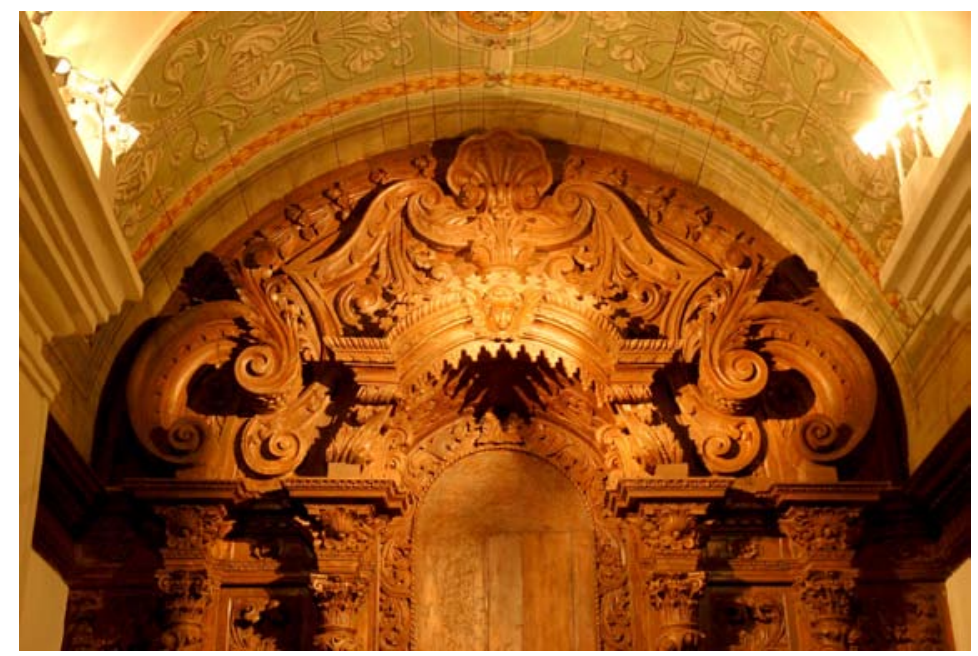

Figura 17: Coroamento do retábulo com as iniciais SM. Fonte: Foto de Marcelo Soares

O vigor dinâmico do harmonioso embelezamento tem como arcabouço conceitual o chamado barroco europeu, aclimatado em Portugal, cuja primeira expressão transplantada para o Brasil, foi tipicamente de acento nacional ${ }^{21}$, conforme o gosto vigente na metrópole; e uma segunda fase, mais suntuosa de influência italiana, batizada como joanino.

Na Igreja de São Francisco Xavier em Belém, os retábulos laterais apresentam uma transição entre os dois estilos, o que leva autores como Ribeiro (2005) e Le Bihan (2005) a acreditar na evidência de reaproveitamentos de um trabalho anterior no corpo da peça, acrescido de nichos laterais e coroamento correspondente a uma produção posterior.

Tal acontecimento talvez se justifique como tentativa de manutenção da unidade visual, haja vista a aplicação de maneira triunfal nos púlpitos e na capela-mor das mudanças ocorridas na gramática barroca em Portugal para o estilo sucedâneo do nacional, transposto quase que simultaneamente em todo mundo lusitano.

O primeiro estilo possui elementos eminentemente clássicos e é marcado no plano arquitetural principalmente com colunas de capitéis e entablamentos da ordem coríntia ou compósita. Em Belém, a opção foi pela ordem compósita.

Entretanto, a característica de maior evidência está na forma espiralada do fuste das colunas cujas influências remontam à coluna santa do antigo templo de Salomão.

\footnotetext{
${ }^{21}$ Conforme Smith (1962), estilo que parece ter sido gestado em Lisboa a partir de 1675, permanecendo até 1720, aproximadamente, ganhando força em todo mundo português, e cuja principal característica está na mudança nas colunas, tendo como antecedentes as portadas românicas. Nomeado na colônia como Nacional Português.
} 
Geralmente trabalhados até o remate com arcos concêntricos inspirados nas portadas românicas, o que não se nota no coroamento na igreja jesuítica em questão.

O plano ornamental contém relevos vegetalistas sobre as colunas, como se vê em todo vocabulário nacional e no corpo da talha das capelas laterais da Igreja de São Francisco Xavier, apropriados da decoração fúnebre da cultura pagã ocidental grecoromana, a saber, parreiras, folhas de acanto e cachos de uva. Acerca da adaptação de tais elementos ao tema sacro Smith diz que:

O motivo provavelmente nasceu na Espanha, onde parece figurar talvez pela primeira vez com caráter monumental na capela-relicário da catedral de Santiago de Compostela encomendada em 1625. Colunas desse tipo apareceram na década de 1630 em Andaluzia e depois em 1650 em Castela. Todas têm em comum o fuste de cinco ou seis espirais iguais [...] Desta coluna, porém o fuste combina espirais cobertas por folhas [...] Em Portugal enriqueceram os fustes espirais com relevos de pássaros, identificados como fênix, ou seja, o símbolo da Ressurreição, e pequenos anjos, os 'meninos'dos velhos contratos, fazendo a colheita eucarística ${ }^{22}$.

Cumpre ressaltar que o próprio Smith, apontando Ayres de Carvalho, apresenta também uma outra versão para a origem do uso das colunas na igreja:

[...]o verdadeiro protótipo da coluna de fuste torso teria sido em Portugal o retábulo marmóreo da capela-mor da igreja da colônia italiana residente em Lisboa, Nssa. Sra. de Loreto, que foi destruído no terremoto de $1755^{23}$.

Controvérsias a parte, o que se viu foi o vasto uso destas colunas em todo reino português com variações ou subtrações do número de peças no modelo. No caso da igreja jesuítica de Belém há duas espirais no corpo da talha, ornadas por vegetais, pássaros, além de pequenas cabeças de anjo. Estas colunas encontram-se separadas por intercolúnios com lambris ornados nas banquetas da primeira e segunda capela em composições com formato de $\mathrm{X}$ e $\mathrm{C}$ - folhas de acanto e/ou volutas com conchas na área interna, nomeado como sendo "a segunda variação do modelo" ${ }^{24}$ do estilo nacional.

Os nichos nos intercolúnios anunciam a segunda fase, mas é no coroamento, que há maior número de correspondências estilísticas com o joanino (Fig. 17, 18 e 19) ${ }^{25}$, como o dossel lambrequinado no plano arquitetônico com pingentes sobre a abertura do camarim.

Os ornamentos desta época apresentam reduzida carga simbólica, conchas, penachos e festões, todos recorrentes no programa de ambiência palaciana. O que dá a chave a Ribeiro (2005) de uma datação provável destes retábulos entre 1725 e 1735.

O que não se pode perder de vista, entretanto, é que embora dentro de padrões estilísticos, todo este árduo trabalho na talha colonial brasileira foi produzido como

\footnotetext{
${ }^{22}$ Smith, 1962: 70.

${ }^{23}$ Ayres de Carvalho apud Smith, 1962: 69-70.

${ }^{24}$ Smith, 1962: 75.

${ }^{25}$ Denominação em homenagem ao Rei D. João V que governou Portugal de 1703 a 1750, como grande mecenas das artes no Reino neste período, importando objetos do evoluído modelo do barroco italiano, para inspiração dos artífices portugueses ou financiando-os para o desenvolvimento do estilo berniniano.
} 
instrumento fundamental do discurso religioso, que para os inacianos estava voltado para “ad majorem Dei gloriam” ("para a maior Glória de Deus”) visando à conversão dos fieis.

Porquanto a valorização do artista não era o propósito da época, fazendo com que tal prerrogativa dificulte o reconhecimento da autoria das peças, através da simples análise do estilo. Muito embora a repetição do padrão escultórico, a influência dos mesmos cânones artísticos, a formação pelos mesmos mestres ou mesmos modelos e o período no qual o irmão encontrava-se em dado lugar funcionem como indicativos para a elucidação deste mistério.

\section{Análise iconográfica ${ }^{26}$}

O tema voltado para Cristo e a Eucaristia adota na gramática visual folhas de parreira e cachos de uvas, que metaforicamente são o vinho e o sangue de Cristo, isto é, a garantia de vida, a imortalidade, o conhecimento e a verdadeira cepa, e, por conseguinte a própria igreja.

A grande quantidade de pássaros, ora com uvas na boca, ora unidos pela boca entre si, representam abnegação, prosperidade e, sobretudo o próprio Filho de Deus, na sua relação entre céu e terra, sacrifício e ressurreição, reforçando a ideia contida no parágrafo anterior.

Muitas vezes esses pássaros estão associados ao pelicano, que na antiguidade, significava 0 amor paternal, por supostamente furar o peito na falta de alimentos para que 0 sangue salvasse sua prole, é associa ao catolicismo com o sangue e à água como bebida da vida para despertar o morto, e/ou a Cristo pela chaga do coração, ou a fênix, que renasce das cinzas.

De qualquer forma, é difícil afirmar de qual ave se trata aqui, haja vista a sua representação não constar de símbolos próprios do pelicano ou fênix, mas o uso da ave como elemento plástico carrega consigo um caráter simbólico de libertação terrena e imortalidade, estando, portanto, diretamente ligada ao Salvador da igreja católica.

Os motivos florais apresentam ramalhetes com botões de rosas e margaridas, que simbolizam o amor e harmonia na atividade celeste dispostos em festões verticais que aparecem entre folhagens, seguindo por todo o arco no coroamento. As rosas e o cálice estão ainda como a taça que recolhe o sangue de Cristo ou como signo das chagas do Filho de Deus.

A vegetação interrompida aqui e ali por grandes conchas, que também aparecem cobrindo os nichos laterais das capelas representam nas referências imagéticas a renovação espiritual oferecida por Deus através da água, para alcançar a eternidade.

Vêem-se folhas de acanto (sobre a mísula das colunas e nas mais diversas disposições em lambris) um arbusto com espinhos, utilizado desde a Idade Média, que aparece como indicativo de uma provação coletiva que, superada, alcança um estado de glória.

\footnotetext{
${ }^{26}$ Esta análise baseou-se em Chevalier y Gheerbrant, 2006.
} 
A própria coluna funciona como sustentáculo da fé, num eixo sagrado de ligação entre céu e terra. $\mathrm{O}$ camarim é o lugar da presença divina, tendo no trono o suporte para a glória, colocado neste espaço como uma porta de passagem para o céu.

A madeira aparece como sinônimo da árvore e da cruz de Cristo tem no cedro, o símbolo da imortalidade. Os anjos com seu corpo etéreo atuam como intermediários nessa conexão entre Deus e o mundo.

\section{A capela do transepto}

Apresenta escala maior na sua estrutura quando comparada às demais capelas da nave, porém mantém a mesma profundidade. Os materiais adotados para a confecção do retábulo foram à madeira e a argamassa, incomum nos setecentos, sendo incorporada à peça num trabalho mais recente.

A mescla destes materiais permite observar na parte inferior da composição plintos almofadados em madeira e a mesa do altar argamassado. No frontal de altar têm-se as letras IHS (que se referem às iniciais de Cristo em grego convertido durante a Idade Média para a forma latina, significando Iesum Hominum Saltvator - Jesus Salvador dos Homens) e uma cruz por cima da letra $\mathrm{H}^{27}$.

O tramo central da banqueta é também em massa e possui coração, cruz, âncora e palmas, sendo as três primeiras às representações das virtudes teologais: caridade, fé e esperança e o último símbolo, a celebração do triunfo da igreja.

O corpo em madeira apresenta igual repertório arquitetônico e decorativo que não fogem à tipologia nacional, tendo na base de preparação o bolo-armênio, coberto por suave policromia (que certamente não é original) com pequenas áreas de douramentos que parecem distanciar-se das folhas de ouro para a barata purpurina, ambos característicos da virada do século XIX para o XX, recuperados na restauração de 1996.

Outra questão a ser tomada em linha de conta diz respeito ao camarim em massa com trono em formato de caixa avantajada e exagerada cobertura bulbosa escamada, que fogem totalmente da tipologia da arte retabilística do XVIII no Brasil, sugerindo a veracidade da assertiva de um trabalho mais recente.

Entre o corpo e o coroamento, na passagem de um registro a outro, há entablamento marcado por friso almofadado em toda extensão do tramo horizontal, com motivos que se assemelham ao da capela-mor.

O inusitado remate composto por uma estética mais plana em relação às demais capelas, mostra peças aplicadas sobre a superfície aparente do tabuado. Tal fato transmite a

\footnotetext{
${ }^{27}$ Schenone (1998) menciona que a sigla já era conhecida no seio da Igreja desde os manuscritos dos Evangelhos no século IV, mas foi somente com as pregações de Bernardino de Siena no século XIV que a devoção ao nome de Jesus foi estabelecida. Sendo reiterada dois séculos depois nas festividades da Circuncisão e da Epifania. A partir desse contexto, a Companhia de Jesus adota o nome do Salvador como insígnia, por meio de acréscimos e variações. As versões podiam conter os cravos, a cruz, a lua, a flor, o coração, as estrelas, os raios de sol e até o próprio Menino Jesus no lugar da cruz, acompanhado ou não de cravos.
} 
impressão de ter havido aqui uma reconstituição de fragmentos de um coroamento de retábulo anterior de talha, onde faltou trabalhar o fundo da obra.

O vocabulário ornamental desta área é guarnecido com cabeças de anjos e anjos de corpo inteiro com as partes íntimas cobertas. Vê se coroa ao centro, cálice com uma rosa, volutas, mascarões com penachos sobre a cabeça e enrolamentos de folhagens que partem do orifício da boca finalizados por flores numa mísula, além de folhas de acanto, também obedecendo ao programa da talha do nacional português. Entretanto, há nas extremidades fragmentos de frontão e conchas que são próprios do joanino.

A variedade de soluções plásticas empregadas alterou significativamente a expressão estética da obra, cuja geratriz está nas reformas ocorridas na igreja, com talvez as mais significativas em 1861 e 1903; acredita-se que o coroamento tenha sido refeito na primeira reforma e o camarim durante a segunda.
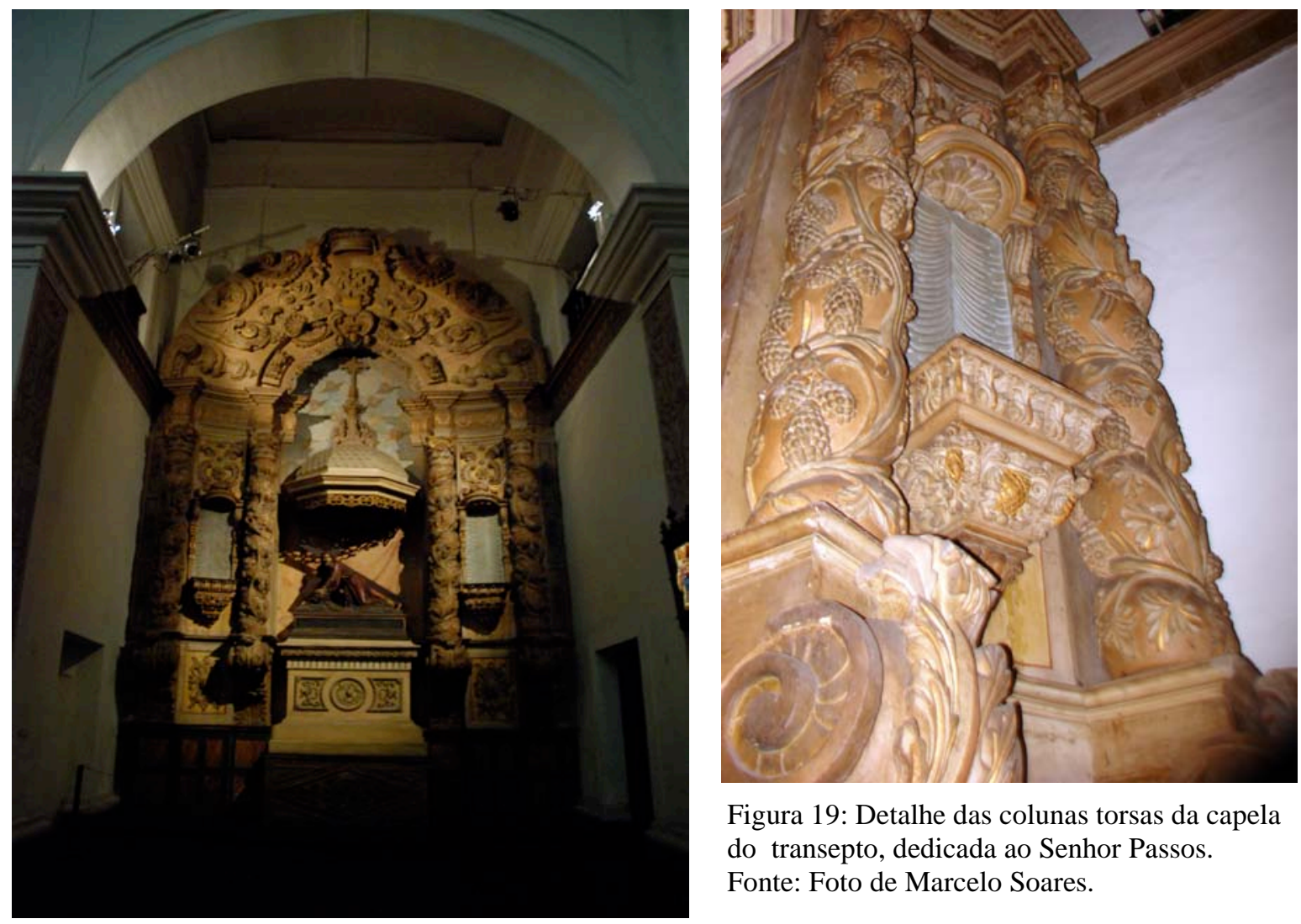

Figura 19: Detalhe das colunas torsas da capela do transepto, dedicada ao Senhor Passos. Fonte: Foto de Marcelo Soares.

Figura 18: Capela do transepto, dedicada ao Senhor dos Passos. Fonte: Foto de Marcelo Soares 


\section{O retábulo da sacristia}

A decoração de talha possui arcaz em jacarandá, com nove gavetas de alças e fechaduras em bronze, e dois armários embutidos nas extremidades do móvel que ocupa um dos lados da parede, sua função era o acondicionamento dos paramentos litúrgicos do celebrante $^{28}$ (Fig. 20).

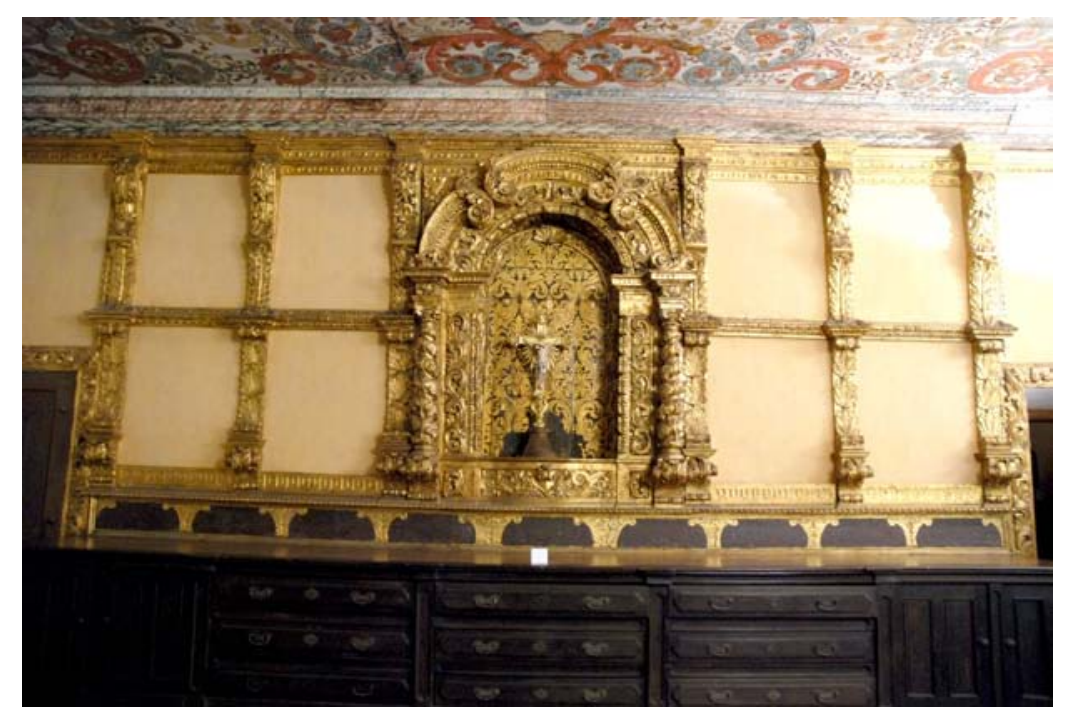

Figura 20: Retábulo da sacristia, com as molduras nas laterais. Fonte: Foto de Marcelo Soares

Sobre o centro da peça vê-se um retábulo, único, aliás, que conservou boa parte do seu douramento, possivelmente por não ser área de circulação pública, sendo recolocadas as áreas inexistentes durante a restauração de 1996.

Ladeiam o retábulo pilastras mísuladas douradas que formam molduras ora cobertas por festões de flores e conchas, distribuídas da cimalha dentilhada até a altura do arcaz, onde são finalizadas por outras pequenas mísulas cobertas por acantos à altura das que se vê na base das colunas.

As formas são fechadas ao longo da parede com réguas horizontais, formando retângulos, que estão relacionados com os elementos próprios do maneirismo, onde a talha

\footnotetext{
${ }^{28}$ Segundo Leite a sacristia “[...]do Pará possuía em 1718 dois grandes armários 'com molduras de jacarandá e pau amarelo por modo xadrez', que já se consideravam velhos em 1760, estando-se então a fazer outros; e entre estas duas datas se fabricou o grande arcaz de 25 gavetas, com fechaduras e argolas de bronze dourado, que tomava um lado e outro da sacristia, encimado ao centro por um retábulo de madeira.” (Leite, 1942: 237). O autor fala da existência de um arcaz com 25 gavetas, então há duas possibilidades aqui: ou o móvel fora substituído com o passar dos anos, ou trata-se de um erro, pois o que se vê assemelha-se da descrição acima, tendo inclusive um retábulo sobre ele, no entanto, possui apenas nove gavetas. Nesse sentido não foram encontradas outras referências que esclareçam o fato.
} 
funciona como emolduramento da pintura, que deve ter se perdido com o correr do tempo, haja vista os espaços encontrarem-se todos vazios ${ }^{29}$.

O estilo repete o programa arquitetônico e iconográfico do nacional português, em proporções menores em relação às capelas da nave, havendo uma coluna torsa de cada lado entre pilastras com enrolamentos de acanto, numa reminiscência do estilo manuelino, ornadas por folhas de parreira e cachos de uva (Fig. 21).

A interessante solução no coroamento, oriunda de outra sobrevivência do estilo anterior ao barroco português (maneirismo), está organizado em arco pleno fechado, com três grandes arquivoltas finalizadas por folhas de acanto, motivo, aliás, pouco comum nos demais retábulos da época no Brasil, sendo arrematado por lambris que se encerram numa cessão quadrangular.

A única abertura existente está ao centro, concebida para abrigar o conjunto do calvário $^{30}$, sendo, ainda segundo Leite (1942), o Cristo em marfim na cruz em ébano; a imagem de São João e Nossa Senhora ao lado em madeira. O camarim é guarnecido por renda da tribuna ornada por acantos. Por trás das figuras, observa-se um fundo preto que provoca interessante contraste com o dourado dos sinuosos arabescos de influência oriental.

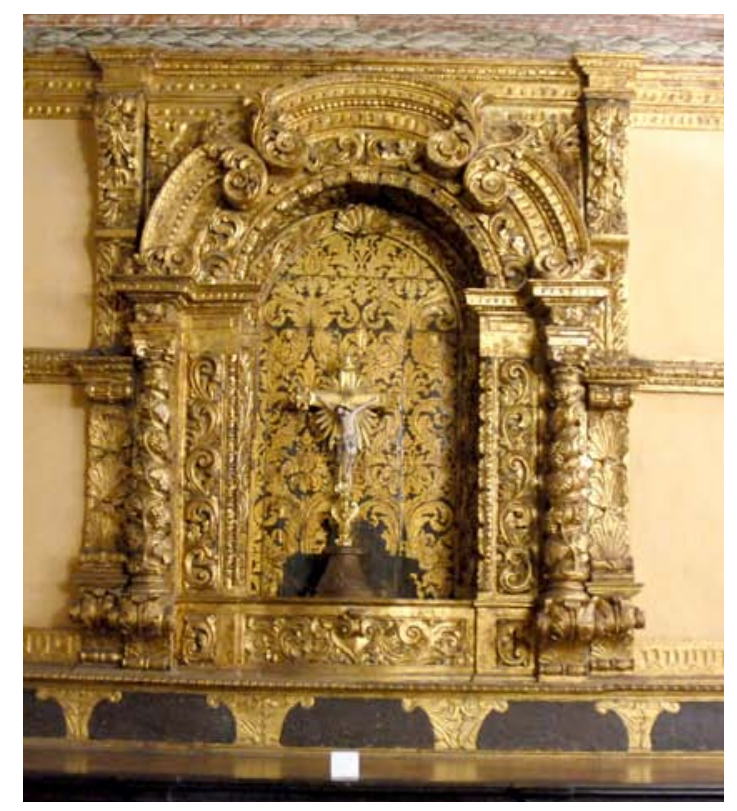

Figura 21: Retábulo da Sacristia. Fonte: Foto de Marcelo Soares

\footnotetext{
${ }^{29}$ Lamego afirma que se tratara de "formosos painéis de baptismo de Christo e a vida de N. Senhora", entretanto, Leite (1942: 237) por sua vez, as identificou no inventário de 1760, como sendo compostos por: 12 quadros, de 3 palmos e meio, todos com vidraças, pendurados no mesmo retábulo; mais 1 de São Francisco de Borja e outro de S. João Francisco de Regis, todos com molduras douradas; mais 4 quadros de 4 palmos; mais 4 maiores de 8 ou 9 palmos; 10 lâminas de cobre, para ornato da sacristia com variedade de preciosas molduras.” (Lamego, 1925: 354).

${ }^{30}$ Hoje, há um crucificado século XIX no lugar em madeira policromada, doado por uma família da região.
} 


\section{Considerações finais}

A antiga Igreja de São Francisco Xavier em Belém, importante marco da atuação jesuítica no século XVIII chega aos dias atuais como testemunho da aventura realizada pelos padres para estabelecer o catolicismo no Pará e Maranhão.

Como ordem destacada da igreja no combate ao movimento protestante, os inacianos deslocavam-se por todo o mundo, onde se fizesse necessário. Na floresta Amazônica não foi diferente, embrenharam-se mata adentro no intuito de alcançar o maior número de fieis, em consonância com os ditames da Igreja pós-tridendina.

Aplicaram o modelo de conversão inaciano pautado na arte como veículo para alcançar a Deus, e para tanto, obedeceram aos programas iconográficos europeus, utilizando-se da mão de obra disponível, dos materiais e técnicas existentes na região, principalmente nos primeiros tempos quando os recursos eram mais escassos.

No Brasil são diversos os exemplos desta mescla cultural (entre europeus, índios e negros) e na igreja de Belém, ocorreu, sobretudo, na estrutura arquitetônica e na fisionomia da imaginária local, o que não foi observado com a mesma intensidade no trabalho de talha.

Considerando a dificuldade de acesso à região, o trânsito dos religiosos e o acúmulo de tarefas para o desenvolvimento do árduo trabalho na talha, a opção foi o que costumeiramente faziam os jesuítas: dedicar uma fazenda como ponto de apoio para o preparo da madeira que atendesse às demandas dos colégios (neste caso o de Belém e de São Luis) e a instalação de oficinas para o melhor aproveitamento dos recursos humanos disponíveis.

O que se observa é que em Belém o aprendizado dos ofícios rendeu resultados cedo, haja vista Leite (1943) apontar, já em 1718, índios, negros e mestiços na qualidade de oficiais carpinteiros e escultores, o que demonstra a eficácia da prática persuasiva e formativa da atuação jesuítica na Amazônia. Embora sem o mesmo destaque mestiço da arquitetura e da imaginária, é possível ver aqui e ali na talha cabeças de anjos com feições regionais, desenvolvidas ao sabor estético europeu apreendido nas oficinas de escultura.

As capelas da nave indicam a existência de momentos sucessivos no processo de feitura das peças apresentando uma transição estilística aplicada segundo o gosto que se instalava na Metrópole. O que torna lícito dizer mesmo com poucos irmãos foi possível com a ajuda local desenvolver um trabalho com resultados muito satisfatórios ainda nas primeiras décadas do XVIII, ainda que a escola jesuítica só tenha atingido o auge nos últimos trabalhos (capela-mor e púlpitos), magnificamente demonstrados com o estilo joanino pleno, atraindo convenientemente a atenção para os conceitos existentes no plano abstrato, arrebatando a alma.

Nota-se na sacristia uma obra de um estilo puro do nacional português na Amazônia brasileira, que de acordo com Smith (1962) costumava ser trabalhado tipologicamente na fase inicial da gramática barroca em Portugal durante o século XVII, sobretudo por oficiais do Norte.

O que leva ao pensamento de que esta talha é um trabalho anterior a todas as outras peças de talha estudadas até aqui, que possivelmente pertencera à suntuária da segunda fase 
construtiva da igreja e que autoriza a suposição da vinda das peças já prontas de navio até o Pará.

Utilizando-se de extremo visualismo a Igreja atinge seus objetivos na colônia com o fausto, o brilho e o ouro sobre a madeira retorcida que aparece como extraordinário instrumento de práticas pedagógico-religiosas, reiteradas pela música, por odores e pela palavra.

Os jesuítas foram expulsos em meados do século XVIII e novos proprietários assumiram o prédio. O tempo passou e a antiga igreja do Colégio de Belém passou por momentos distintos até o prédio ser restaurado em 1996, e transformado num importante museu no Pará, o Museu de Arte Sacra, onde entre outros se expõe as obras remanescentes da época jesuítica, e se destacam no interior do templo os retábulos setecentistas na madeira nua, o que parece acrescentar um outro valor ao elemento formal e estilístico concebido durante o Brasil colônia, que é a apreciação do visitante a preciosa madeira do cedro vermelho; uma opção que nega a força coercitiva dourada de outrora e sob este aspecto a máquina teatral barroca perde em efeitos.

\section{Referências}

Baena, Antônio Ladislau Monteiro (1969). Compêndio das eras da província do Pará. Belém: Universidade Federal do Pará.

Bazin, Germain (1983). A Arquitetura religiosa barroca no Brasil. Rio de Janeiro: Recordm 1983, 2 v. (Título original: L’architecture religieuse baroque au Brésil. Paris: Plon, 1956-58)..

Bettendorf, Pe. João Felipe (1990). Crônica dos padres da Companhia de Jesus no estado do Maranhão. 2. ed. Belém: Fundação Cultural do Município do Pará Tancredo Neves. Secretaria de Estado de Cultura.

Bogea, K. S.; Ribeiro, E. S.; Brito, S. R. S. (2002). Os olhos da alma: escola maranhense de imaginária. São Luís, São Paulo: Kátia S. Bogéa, v.1.

Bury, John Bernard (1991). Arquitetura e arte no Brasil colonial. Rio de Janeiro: Nobel.

Brasão, Eduardo (1938). Relações exteriores de Portugal: reinado de D. João V. Porto: [S.n], 1938. v. I-III.

Chevalier, Jean; Gheerbrant, Alain (2006). Dicionário de símbolos: mitos, sonhos, costumes, gestos, formas, figuras, cores, números. Tradução Vera da Costa e Silva, Raul de Sá Barbosa, Angela Melim e Lúcia Melim. 20. ed. Rio de Janeiro: Ed. José Olympio.

Coelho, Geraldo Mártires; Coelho, Alan Watrin (2005). “Visibilidade e encobrimento do monumento jesuítico em Belém”. In: Feliz Lusitânia: Museu de Arte Sacra. Belém: SECULT. 
Costa, Lúcio (1941). “A arquitetura dos jesuítas no Brasil”. Revista do Patrimônio Histórico e Artístico Nacional, Rio de Janeiro, n. 5.

Cunha, Luiz Antônio (2005). O Ensino de ofícios artesanais e manufatureiros no Brasil escravocrata. 2. ed. São Paulo: UNESP.

Daniel, Pe. João (2004). Tesouro descoberto no máximo rio Amazonas: 1722-1776. Rio de Janeiro: Contraponto, v. 1 y 2.

D’azevedo, João Lúcio (1999). Jesuítas no Grão-Pará. Belém: SECULT.

Eisenberg, José (2000). As Missões Jesuíticas e o Pensamento Moderno: encontros culturais, aventuras teóricas. Belo Horizonte: UFMG.

Ferreira-Alves, Natália Marinho (2004). "O Douramento e a policromia no norte de Portugal à luz da documentação dos séculos XVII e XVIII”. Revista da Faculdade de Letras, Ciências e Técnicas do Patrimônio, Porto, v. III, p. 85-93 (I Série). Disponível em: http://ler.letras.up.pt/uploads/ficheiros/4084.pdf. Acesso em: 10 out. 2008.

Ferreira-Alves, Natália Marinho (2003). "Pintura, talha e escultura no norte de Portugal”. Revista da Faculdade de Letras, Ciências e Técnicas do Patrimônio, Porto, v. II, p. 735-755, 2003. (I Série). Disponível em: http://repositorio.up.pt/aberto/ handle/10216/8402. Acesso em: 08 out. 2008.

Flexor, Maria Helena (1993/96). Oficiais mecânicos (artesãos) na cidade de Salvador e São Paulo no período colonial. Belo Horizonte: [S.n].

Freire, Luiz Alberto Ribeiro (2004). "Gênese formal e simbólica do retábulo de N. Sr. do Bom Fim da Bahia e seus derivados". Revista Ohun, [Salvador?], ano 1, n.1. Disponível em: <http://www.revistaohun.ufba.br/html/retabulo.html.> Acesso em: 20 jan. 2009. Programa de Pós-Graduação em Artes Visuais da Escola de Belas Artes da Universidade Federal da Bahia PPG-AV-EBA-UFBA.

Govoni, Pe. Ilário (2008). Transcrição do inventário jesuítico do Pará: ARSI, BRAS 28,8, Roma. Texto digitado em Belém, em 21 set. 2008.

Hill, Marcos (1998). A Talha em Évora: séculos XVII-XVIII. Évora: Universidade de Évora. Centro de História da Arte.

Hill, Marcos (2009). Talha e pintura colonial Luso Brasileira. Ouro Preto: UFOP, 2009. Gravação de aula no Curso de Especialização em Arte e Cultura Barroca.

Lamego, Alberto (1925). A Terra Goytacá: á luz de documentos inéditos. Bruxelles, Paris: L’Édition D’Art Gáudio. t. III.

Le Bihan, Joseph Marie (2005). “A Igreja de Santo Alexandre: exemplo ímpar da poética jesuítica na Amazônia”. In: Feliz Lusitânia: Museu de Arte Sacra. Belém: SECULT, v. 3.

Leite, Pe. Serafim (1942). “O Colégio de Santo Alexandre e a Igreja de São Francisco Xavier, de Belém do Grão Pará”. Revista do Serviço do Patrimônio Histórico e Artístico Nacional, Rio de Janeiro, n. 6. 
Leite, Pe. Serafim (1943). História da Companhia de Jesus no Brasil. Rio de Janeiro: Imprensa Nacional, 1943. t. 3 e 4. Norte. I Fundações e Entradas, séculos XVII e XVIII.

Leite, Pe. Serafim (1943). Artes e ofícios dos jesuítas no Brasil: 1549-1760. Lisboa, Rio de Janeiro: Brotéria. Livros de Portugal.

Lisboa, João Francisco (1976). Crônica do Brasil colonial: apontamentos para a história do Maranhão. Petrópolis, Brasília: Vozes. INL.

Lustosa, Dom Antônio de Almeida (1992). Dom Macedo Costa: bispo do Pará. 2. ed. Belém: SECULT.

Morales, Pe. José (1860-1874). História da Companhia de Jesus na extinta província do Maranhão e Pará. Rio de Janeiro: Typ do Commercio, de Brito e Braga.

Miller, René Fülöp (1935). Os Jesuítas e o Segredo do seu Poder. Tradução Álvaro Franco. Porto Alegre: Livraria do Porto.

Oliveira, Myriam Andrade Ribeiro de (2005). “A Epopéia jesuítica no Amazonas e sua obra arquitetônica e escultórica”. In: Feliz Lusitânia: Museu de Arte Sacra. Belém: SECULT, 2005. v. 3.

Pennick, Nigel (1989). Geometria sagrada: simbolismo e intenção nas estruturas religiosas. Tradução Alberto Feltre. São Paulo: Editora Pensamento.

Ripa, Cesare (1992). Iconologia. Milano: Editori Associati S.p.A. TEA Arte gennaio.

Santos, Paulo F. (1951). O Barroco e o jesuítico na arquitetura do Brasil. Rio de Janeiro: Kosmos.

Schenone, Héctor H. (1992). Iconografia del arte colonial: los santos. Buenos Aires: Fundación Tarea, v. 1.

Schenone, Héctor H. (1998). Jesus Cristo. Buenos Aires: Fundación Tarea.

Smith, Robert (1962). A Talha em Portugal. Lisboa: Livros Horizonte.

Toledo, Benedito Lima de (1983). “Do século XVI ao início do século XIX: maneirismo, barroco e rococó”. In: ZANINI, Walter (Coord.). História geral da arte no Brasil. São Paulo: Instituto Walter Moreira Sales.

Vale, Teresa Leonor M. (2003). “Da Igreja combatente à Igreja triunfante”. In: Revista Brotéria. Cristianismo e cultura. Lisboa: [S.n.], v. 157, n. 5. nov. 